Research note

\title{
First record of Nelsonia goldmani in the state of Morelos, Mexico
}

\author{
Primer registro de Nelsonia goldmani en el estado de Morelos, México \\ Francisco X. González-Cózatl ${ }^{*}$, Rachel M. Vallejo, Elizabeth Arellano \\ Centro de Investigación en Biodiversidad y Conservación, Universidad Autónoma del Estado de Morelos, Av. Universidad 1001, Chamilpa, 62209 Cuernavaca, \\ Morelos, Mexico \\ Received 19 June 2015; accepted 2 December 2015 \\ Available online 22 April 2016
}

\begin{abstract}
We report Nelsonia goldmani in the state of Morelos for the first time. This new record constitutes a range extension of the distribution of this species of over $100 \mathrm{~km}$ to the southeast of the nearest known localities. The collecting site is located less than $40 \mathrm{~km}$ south of Mexico City, within the limits of two natural protected areas that have been surveyed for more than half century. The fact that previous inventories in this region had not registered the occurrence of this Mexican endemic and endangered species, confirms its rareness and the need of further exhaustive surveys to accurately document Mexican biodiversity.

All Rights Reserved (C 2016 Universidad Nacional Autónoma de México, Instituto de Biología. This is an open access item distributed under the Creative Commons CC License BY-NC-ND 4.0.
\end{abstract}

Keywords: Nelsonia goldmani; Trans-Mexican Volcanic Belt; Endemic; Rare; Endangered

\section{Resumen}

Se documenta Nelsonia goldmani en el estado de Morelos por primera vez. Este nuevo registro constituye una extensión del rango de distribución de esta especie de poco más de $100 \mathrm{~km}$ hacia el sureste de las localidades conocidas más cercanas. La localidad de recolecta se ubica a menos de $40 \mathrm{~km}$ al sur de la ciudad de México, en los límites de 2 aéreas naturales protegidas que han sido muestreadas por más de medio siglo. El hecho de que los inventarios anteriores en esta zona no hayan registrado la presencia de esta especie, endémica y amenazada de México, confirma su rareza y la necesidad de intensificar esfuerzos para documentar de forma precisa la biodiversidad mexicana.

Derechos Reservados (C) 2016 Universidad Nacional Autónoma de México, Instituto de Biología. Este es un artículo de acceso abierto distribuido bajo los términos de la Licencia Creative Commons CC BY-NC-ND 4.0.

Palabras clave: Nelsonia goldmani; Eje neovolcánico; Endémica; Rara; Amenazada

The genus Nelsonia is an endemic group of medium size rodents restricted to montane regions in Mexico that includes only two species; Nelsonia neotomodon is found in the Sierra Madre Occidental and Nelsonia goldmani is distributed in the west-central portion of the Trans-Mexican Volcanic Belt (Engstrom, Sánchez-Herrera, \& Urbano-Vidales, 1992; GarcíaMendoza \& López-González, 2005; Musser \& Carleton, 2005).

\footnotetext{
* Corresponding author.

E-mail address: xavier@uaem.mx (F.X. González-Cózatl).

Peer Review under the responsibility of Universidad Nacional Autónoma de México.
}

Although both taxa were described more than 100 years ago, little is known on their natural history. Within the TransMexican Volcanic Belt, N. goldmani has only been recorded in the states of Michoacán, Jalisco, Colima, and Estado de México (Fig. 1; Engstrom et al., 1992; Genoways \& Jones, 1968; Glendinning, 1992; Hooper, 1954; Merriam, 1903). It is considered a rare species because of its sparse representation in scientific collections; only 42 specimens have been deposited in collections in the United States and Mexico (León, 2013). At present, this species is subject to special protection by the Mexican government (Semarnat, 2010) and has been categorized as endangered by the International Union for 


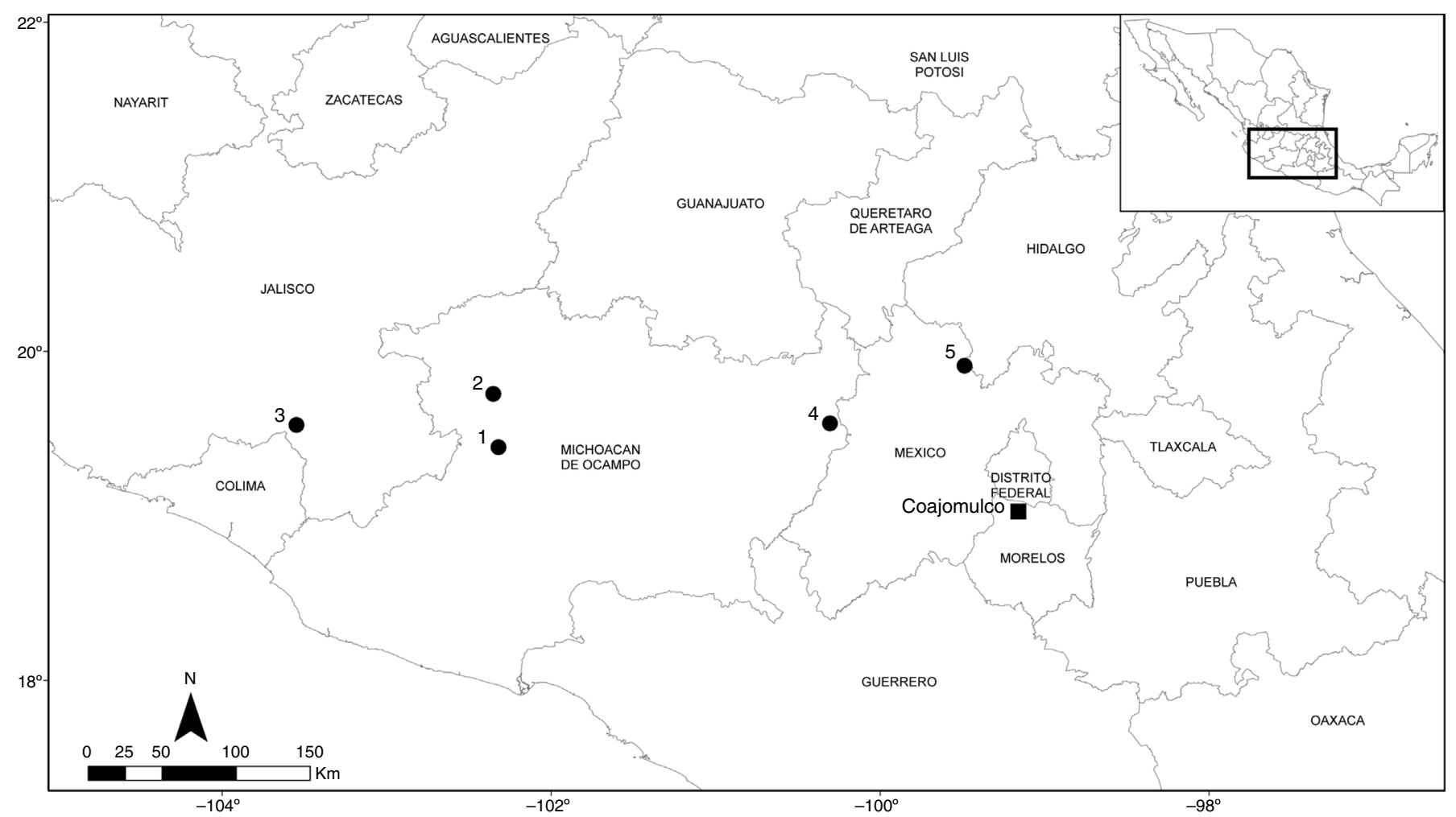

Figure 1. First record of Nelsonia goldmani in the state of Morelos (solid square) and previously reported localities in the Trans-Mexican Volcanic Belt (solid dots): 1, cerro Tancítaro; 2, cerro Patamban; 3, Nevado de Colima; 4, sierra Chincua, and 5, Jilotepec (Engstrom et al., 1992; Genoways \& Jones, 1968; Glendinning, 1992; Hooper, 1954; Merriam, 1903).

Conservation of Nature (Álvarez-Castañeda \& Castro-Arellano, 2008). In this paper, we report the first record of $N$. goldmani in the state of Morelos which represent a range extension of its distribution.

As a result of an ongoing inventory of the mammals of Morelos, continuous surveys have been performed in the temperate forest of this region during the last years. Collecting methods included the use of Sherman traps. Traps were baited with a mixture of sunflower seeds and oats. Specimens were prepared as conventional museum vouchers following standard techniques (Hall, 1981) and deposited in the Colección de Mamíferos, Centro de Investigación en Biodiversidad y Conservación, Universidad Autónoma del Estado de Morelos (CMC).

On 24 February 2011, we collected one young adult female of $N$. goldmani (CMC 2894) at $6.5 \mathrm{~km}$ E Coajomulco (along the old railroad México-Cuernavaca), Municipio Tepoztlán, More$\operatorname{los}\left(19^{\circ} 02.53^{\prime} \mathrm{N}, 99^{\circ} 15.57^{\prime} \mathrm{W}\right)$ at $2,514 \mathrm{~m}$ in elevation (Fig. 1). No evidence of reproductive activity was found on this animal. Because this specimen was a juvenile and lacked the diagnostic external features of a fully developed individual, it was originally identified as Peromyscus sp. Nonetheless, a later reevaluation of dental and cranial features revealed that this specimen represents a specimen of $N$. goldmani. The third upper molars (Fig. 2) and second and third lower molars display the unique pattern described for Nelsonia (Merriam, 1897). In addition, unlike $N$. neotomodon, our specimen has a distinct anteorbital notch in the anterior base of the zygomatic process with a vertical lamella well marked, forming a spine when viewed from above, a diag-
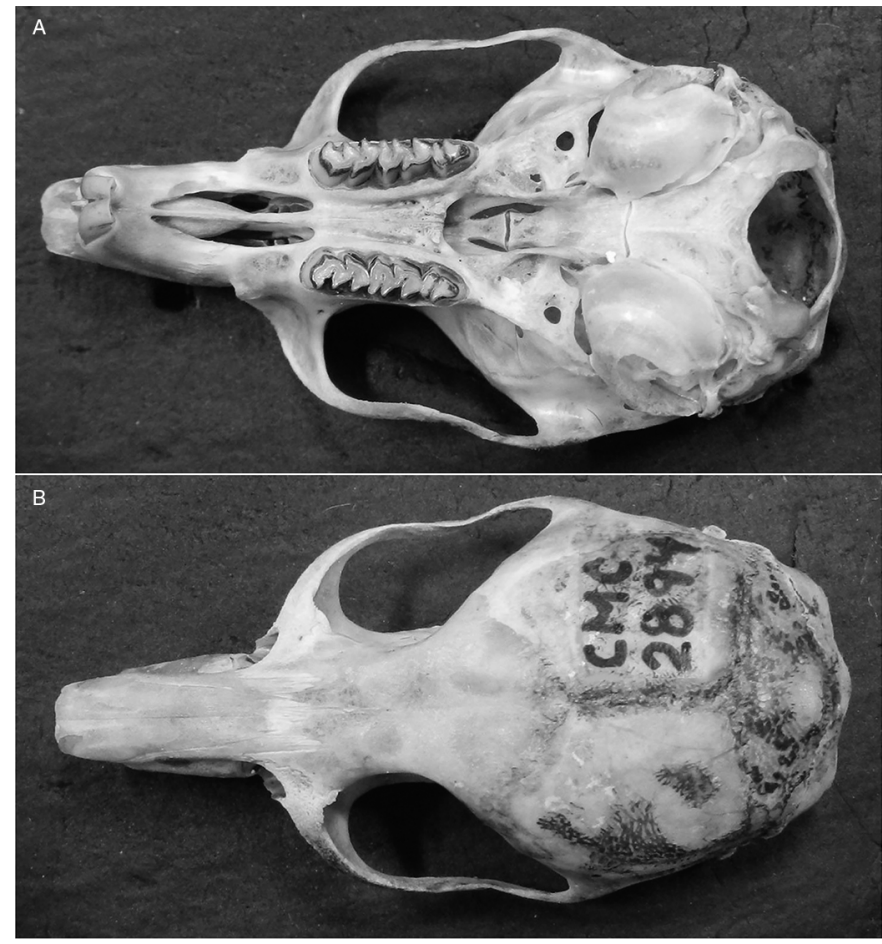

Figure 2. (A) Ventral view of the cranium of a young female Nelsonia goldmani. Note the particular pattern of the third upper molar, which is divided into two subtriangular lobes, a diagnostic feature for the genus. (B) Dorsal view of the same cranium. It can be observed the distinct anteorbital notch in the anterior base of the zygomatic process, with a vertical lamella well marked that forms a spine, a feature that distinguishes $N$. goldmani from $N$. neotomodon. 
nostic feature of $N$. goldmani (Fig. 2; Merriam, 1903). The upper parts are dark gray and the under parts are white with some blackish patches. Sides display some pale ochraceous spots right below the ear line. The hind feet are mostly white with some blackish color on the upper parts. Tail is well haired, dark brown and slightly paler ventrally, but not sharply bicolor.

External measurements $(\mathrm{mm})$ of this individual are: total length 207; vertebral length tail 101; hind foot length 27; ear length 22. Body mass is $25 \mathrm{~g}$. Cranial measurements (mm; taken to the nearest $0.1 \mathrm{~mm}$ using a digital caliper), most of them comparable to those reported by Engstrom et al. (1992), are as follows: greatest length of skull 30.4; length of rostrum 11.5; breadth of zygomatic plate 3.3 ; mastoid breadth 12.8; zygomatic breadth 15.7; post-orbital constriction 4.7; breadth of rostrum 4.8; width of interparietal bone 11.2; breadth across molars 6.0; post-dental palatal width 5.7 ; depth of skull 10.7 . Only length of rostrum, zygomatic breadth, and breadth of rostrum were slightly different $(0.1 \mathrm{~mm}$ of the lower limit range) to those recorded by Engstrom et al. (1992).

The specimen of $N$. goldmani was collected in an oak forest, where the most abundant species are Quercus rugosa and Quercus castanea. This forest is also characterized by the presence of other tree species typical of cloud forests, including Clethra mexicana, Styrax ramirezii, and Symplocos prionophylla. Trees were commonly covered with epiphytes. The forest is located on a moderate slope facing south. Other rodent species collected at this site were Peromyscus difficilis, Peromyscus hylocetes, Microtus mexicanus, and Reithrodontomys microdon.

Although it is known that $N$. goldmani is distributed along the Trans-Mexican Volcanic Belt, the specimen collected at Tepoztlán Municipality represents the first record for the state of Morelos and a range extension of approximately $100 \mathrm{~km}$ to the south-southeast of the nearest known record (Fig. 1). The closest locality previously known for $N$. goldmani is Cañada de la Ermita, $4 \mathrm{~km} \mathrm{~N}$ Dexcaní El Alto, $2 \mathrm{~km} \mathrm{S,} 3.5 \mathrm{~km} \mathrm{E}$ Jilotepec, Estado de México (Fig. 1; Engstrom et al., 1992). The second closest locality is Sierra Chincua, near Angangeo, Michoacán (Glendinning, 1992), about $130 \mathrm{~km}$ southeast to the first record for Morelos (Fig. 1). Interestingly, the new locality for $N$. goldmani is within the limits of the Corredor Biológico Chichinautzin and the Parque Nacional Tepozteco, two natural protected areas that are located approximately $30-40 \mathrm{~km}$ south from México City. This region has been subject to mammal surveys for more than half a century (Álvarez-Castañeda, 1996; Davis \& Russell, 1953, 1954; Santillán-Alarcón, Lozano, Ortíz, \& Porcayo, 2010), but none of these previous inventories had registered the occurrence of this species. Certainly, this fact confirms the rareness of this taxon and the need of further exhaustive surveys to have a more complete view of the Mexican biodiversity.

We thank Mariana González-Téllez for help with fieldwork and Ana L. Villalba for her assistance in preparing Figure 1.
We are grateful to Noé González Ruiz and one anonymous reviewer for providing helpful comments on an early version of the manuscript. Collecting permit FAU-FLO 0025 was issued to Francisco X. González-Cózatl.

\section{References}

Álvarez-Castañeda, S. T. (1996). Los mamíferos del estado de Morelos. La Paz, B.C.S.: Centro de Investigaciones Biológicas del Noroeste, S. C.

Álvarez-Castañeda, S. T., \& Castro-Arellano, I. (2008). Nelsonia goldmani. The IUCN Red List of threatened species. Version 2015.1. www.iucnredlist.org/

Davis, W. B., \& Russell, R. J. (1953). Aves y mamíferos del estado de Morelos. Revista de la Sociedad Mexicana de Historia Natural, 14, $77-147$.

Davis, W. B., \& Russell, R. J. (1954). Mammals of the Mexican state of Morelos. Journal of Mammalogy, 35, 63-80.

Engstrom, M. D., Sánchez-Herrera, O., \& Urbano-Vidales, G. (1992). Distribution, geographic variation, and systematic relationships within Nelsonia (Rodentia: Sigmodontinae). Proceedings of the Biological Society of Washington, 105, 867-881.

García-Mendoza, D., \& López-González, C. (2005). Diminutive woodrat (Nelsonia neotomodon) in Chihuahua, Mexico. Southwestern Naturalist, 50, 503-506.

Genoways, H. H., \& Jones, J. K. (1968). A new mouse of the genus Nelsonia from Southern Jalisco, Mexico. Proceedings of the Biological Society of Washington, 81, 97-100.

Glendinning, J. I. (1992). Range extension for the diminutive woodrat, Nelsonia neotomodon in the Mexican transvolcanic range. Southwestern Naturalist, 37, 92-93.

Hall, E. R. (1981). The mammals of North America. 2nd ed. (vol. 1) New York: John Wiley \& Sons.

Hooper, T. E. (1954). A synopsis of the Cricetine rodent genus Nelsonia. Occasional papers of the Museum of Zoology, no. 558. University of Michigan Press.

León, M. A. (2013). Ubicación filogenética con caracteres moleculares de la rata de monte (Nelsonia goldmani), endémica del Eje Neovolcánico Transversal. Tesis de maestría. Instituto de Biología, Universidad Nacional Autónoma de México.

Merriam, C. H. (1897). Nelsonia neotomodon, a new genus and species of Murine rodent from Mexico. Proceedings of the Biological Society of Washington, 11, 277-279.

Merriam, C. H. (1903). Four new mammals, including a new genus (Teanopus), from Mexico. Proceedings of the Biological Society of Washington, 16, 79-82.

Musser, G. G., \& Carleton, M. D. (2005). Family Cricetidae. In D. E. Wilson, \& D. M. Reeder (Eds.), Mammal species of the world: a taxonomic and geographic reference (pp. 955-1189). Washington, DC: Smithsonian Institution Press.

Santillán-Alarcón, S., Lozano, M. A., Ortíz, A. L., \& Porcayo, D. (2010). Estado actual de la masofauna silvestre. In J. R. Bonilla, V. M. Mora, J. Luna-Figueroa, H. Colín, \& S. Santillán-Alarcón (Eds.), Biodiversidad, conservación y manejo en el Corredor Biológico Chichinautzin. Condiciones actuales y perspectivas (pp. 123-134). Cuernavaca: Universidad Autónoma del Estado de Morelos - Gobierno del Estado de Morelos.

Semarnat. (2010). Norma Oficial Mexicana NOM-059-ECOL-2010, Protección ambiental - Especies nativas de México y de flora y fauna silvestres - Categorías de riesgo y especificaciones para su inclusión, exclusión o cambioLista de especies en riesgo. Diario Oficial de la Federación. 30 de diciembre de 2010. Segunda Sección, México. 